\title{
耳下腺と対側顎下腺に同時に認めた多形腺腫
}

\author{
瀧 正勝1) · 正垣 一博2) - 島田 剛敏2) - 久 育男2) \\ 四八宮 隆3)・木村 隆保4) - 立本 圭吾5)
}

\section{Pleomorphic Adenomas in Parotid Gland and Submandibular Gland of the Other Side; A Case Report}

\author{
Masakatsu Taki \\ (Omihachiman City Hospital)
}

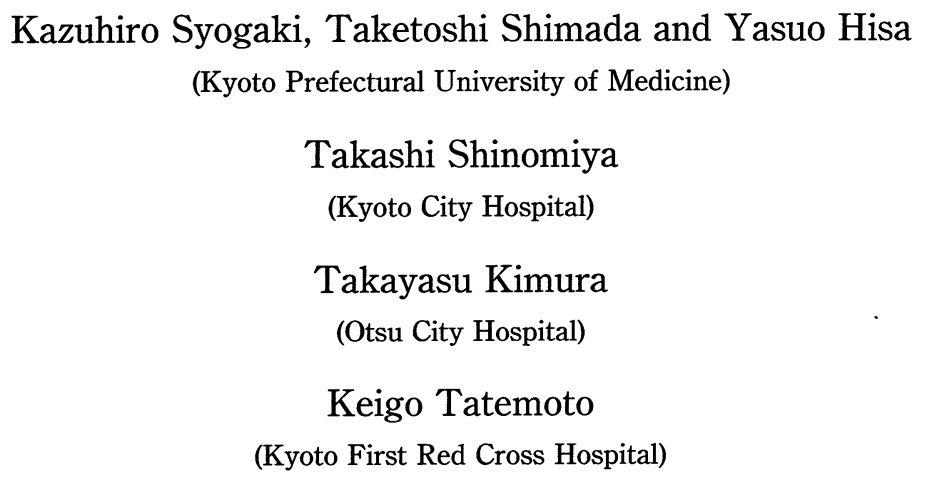

Pleomorphic adenomas in several salivary glands are rare. We report a patient with pleomorphic adenomas in the right parotid gland and the left submandibular gland. Preoperative MRI and neck echography revealed masses in the right parotid gland and the left submandibular gland. Right superficial parotidectomy and left submandibular sialoadenectomy were performed and the histopathologic diagnosis was pleomorphic adenoma, with no suggestion of malignancy and metastasis. To our knowledge, there have been no previous reports of pleomorphic adenoma both in the parotid gland and in the submandibular gland of the other side.

Key words : pleomorphic adenoma, parotid gland, submandibular gland

はじめに

耳下腺腫瘍は一側性, 単発性であることが多く, 多発 性腫瘍のほとんどはワルチン腫瘍であり，多形腺腫が複 数の大唾液腺にみられることは非常にまれである.われ われが渉猟しえた限りでは, 複数の大唾液腺に多形腺腫 を同時に認めた症例は，国内では両側耳下腺に認められ た10数例の報告のみである. 今回われわれは右耳下腺と
左顎下腺に同時に認められた多形腺腫の 1 例を経験した ので，その概略を述べるとともに，若干の考察を加えて 報告する.

\section{症 例}

患者 : 29歳, 男性.

主訴 : 右耳下部腫脹.
1）近江八幡市民病院耳鼻咽喉科

3）京都市立病院耳鼻咽喉科

5）京都第一赤十字病院耳鼻咽喉科
2) 京都府立医科大学耳鼻咽喉科学教室

4）大津市民病院耳鼻咽喉科 
既往歷：13歳 䯣膜炎.

家族歴 : 弟 ネフローゼ症候群.

現病歷 : 平成 10 年 2 月頃, 感冒にて近医内科受診し た際，右耳下部腫脹を指摘されていたが，特に無症状の ため放置していた，平成11年 2 月中旬になり，指摘され ていた腫脹が気になり始め，精查を希望し近医耳鼻咽㮢 科を受診したところ，右耳下腺腫瘍を疑われ，2 月25日 京都府立医科大学耳鼻咽喉科へ紹介となった。

現症：右耳下部に $34 \times 25 \mathrm{~mm}$ の腫瘤を触知した。表 面は平滑で弾性硬であり, 压痛, 癒着は認めず，顔面神 経麻痺などの神経症状も認められなかった。屯た，左顎
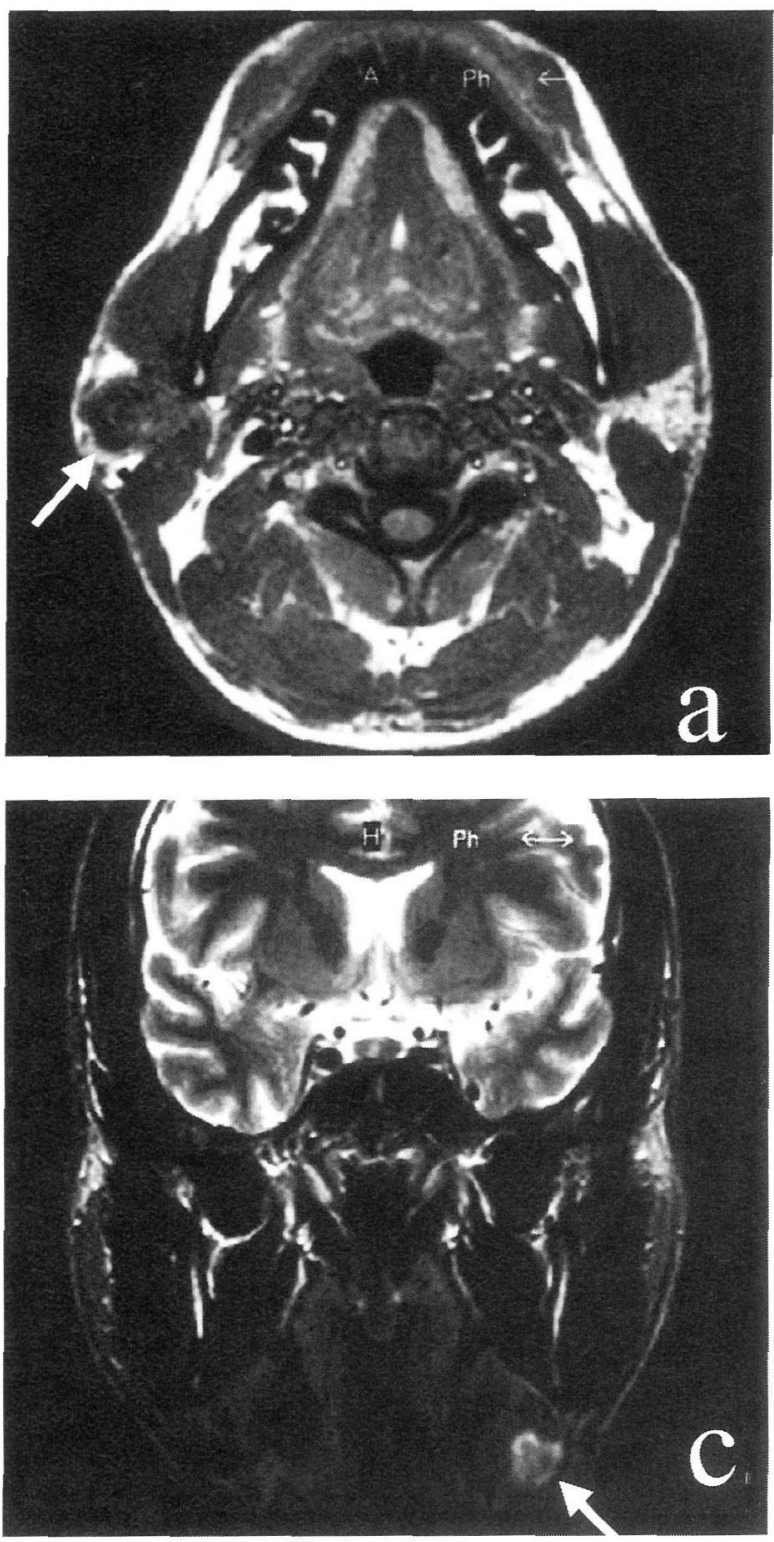

下部にも腫瘤を触知したが，右耳下部の腫瘤よりる硬く， 自発痛，压痛，癒着を認めず，ぬた患者によると幼少時 より認めるとのことで，非特異的リンパ節腫脹と考觉ら れた。

検 査

・右耳下部の穿刺吸引細胞診：クラス II, 多形腺腫.

- MRI 検査 : 右耳下腺下極に径約 $25 \mathrm{~mm}$ の $\mathrm{T} 1$ 強調 画像で低信号, T2 強調画像で高信号の内部は不均一で 造影効果の良い境界明膫な腫瘤を認めた。むた，左顎下 腺内に径約 $10 \mathrm{~mm}$ の $\mathrm{T} 1$ 強調画像で低信号, $\mathrm{T} 2$ 強調画 像で高信号の内部は注济均一で, 造影効果の乏しい境界

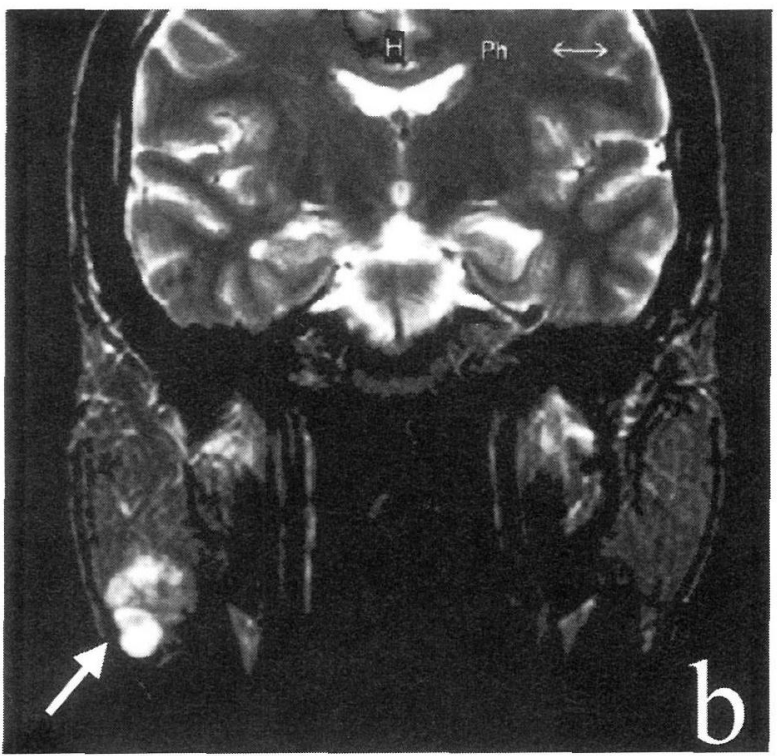

図 1 MRI 検查

右耳下腺下極に $\mathrm{T} 1$ 強調画像で低信号 ( $\mathrm{a}$; 水平断), T2 強調画像で高信号 (b; 冠状断)の腫瘤を認めた. 左靧下 腺内には T2 強調画像で高信号 ( c ; 冠状断) の腫瘤陰影 を認めた。 
明瞭な腫瘤を認めた(図 1 ).

そのため左顎下部腫瘤はリンパ節腫脹ではなく, 左顎 下腺腫瘍と考光精査を進めた。

- 超湆波検査 : 右耳下腺下極に $23 \times 32 \times 17 \mathrm{~mm}$ の表 面はやや粗く, 境界明瞭, 内部は low echoic で不均一 な分葉状の腫瘤を認めた。また，左顎下腺内に $17 \times 19 \times$ $12 \mathrm{~mm}$ の表面平滑で, 境界明瞭, 内部はlow echoic で 均一の腫瘤を認めた(図 2 ).

その核か明らかなリンパ節腫脹は認めなかった。

治療：以上より右耳下腺腫瘍に加光, 左顎下腺腫瘍の
存在当確認し, 患者にも説明, 了承の上, 平成11年 3 月 24 日全身麻酔下に両腫瘍の摘出術を施行した。

手術所見：屯ず左顎下腺摘出術を施行した。左顎下部 に切開を加え, 広頸筋直下で剥離を進めると顔面神経辺 縁枝の直下に左顎下腺より突出する腫瘤を確認し, 注意 深く剥離した。顔面動静脈, 舌神経は温存し, ワルトン 管を結禁, 切離し左顎下腺を摘出した。次いで右耳下腺 浅葉切除術を施行した。右耳前部より下顎にかけ $\mathrm{S}$ 字状 切開を加光剥離を進めると, 腫瘍は耳下腺下極に存在し た. 胸鎖乳突筋前縁を露出し顔面神経本幹を確認した.
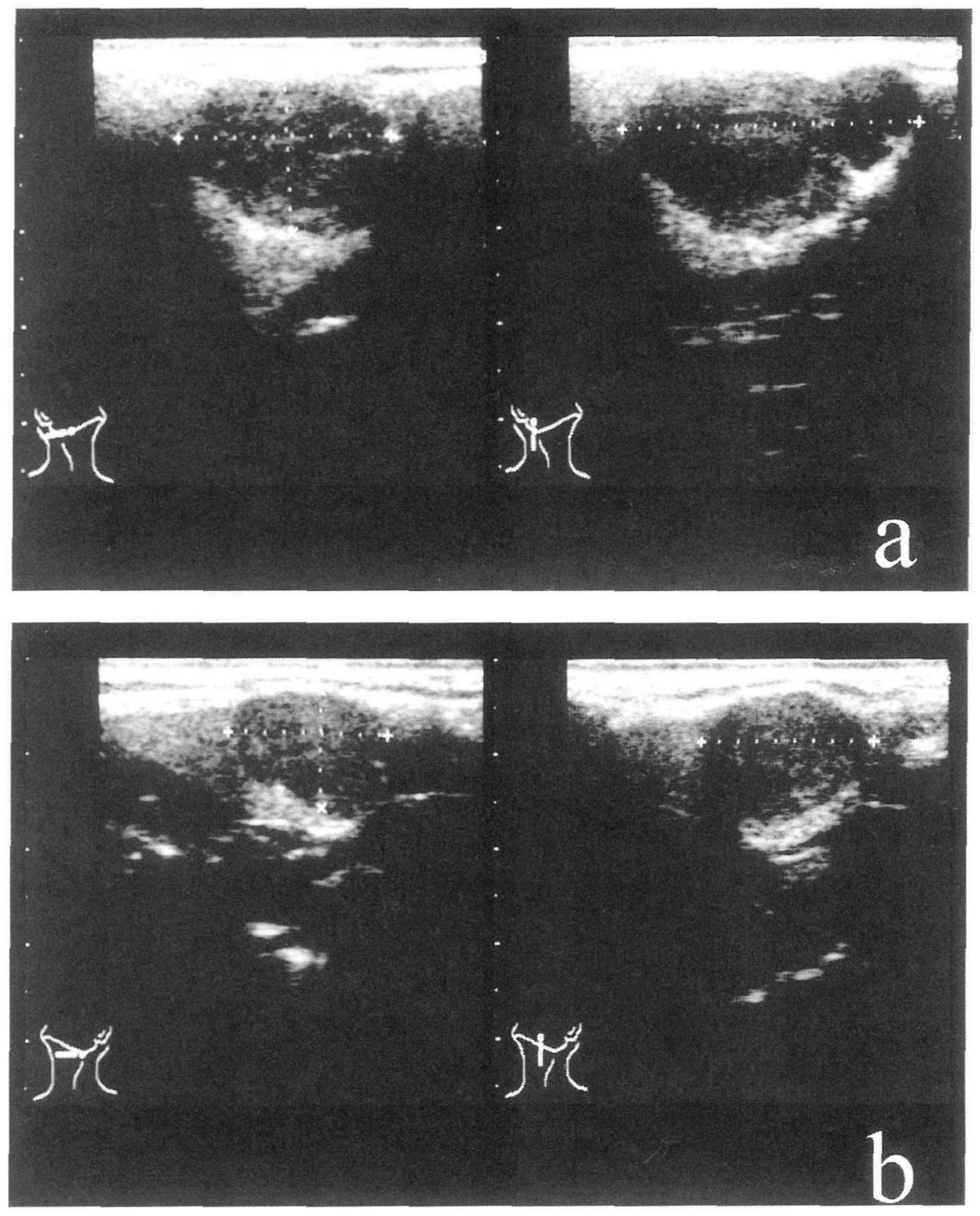

図 2 超音波検査

a : 右耳下腺腫瘍, b : 左顎下腺腫瘍 

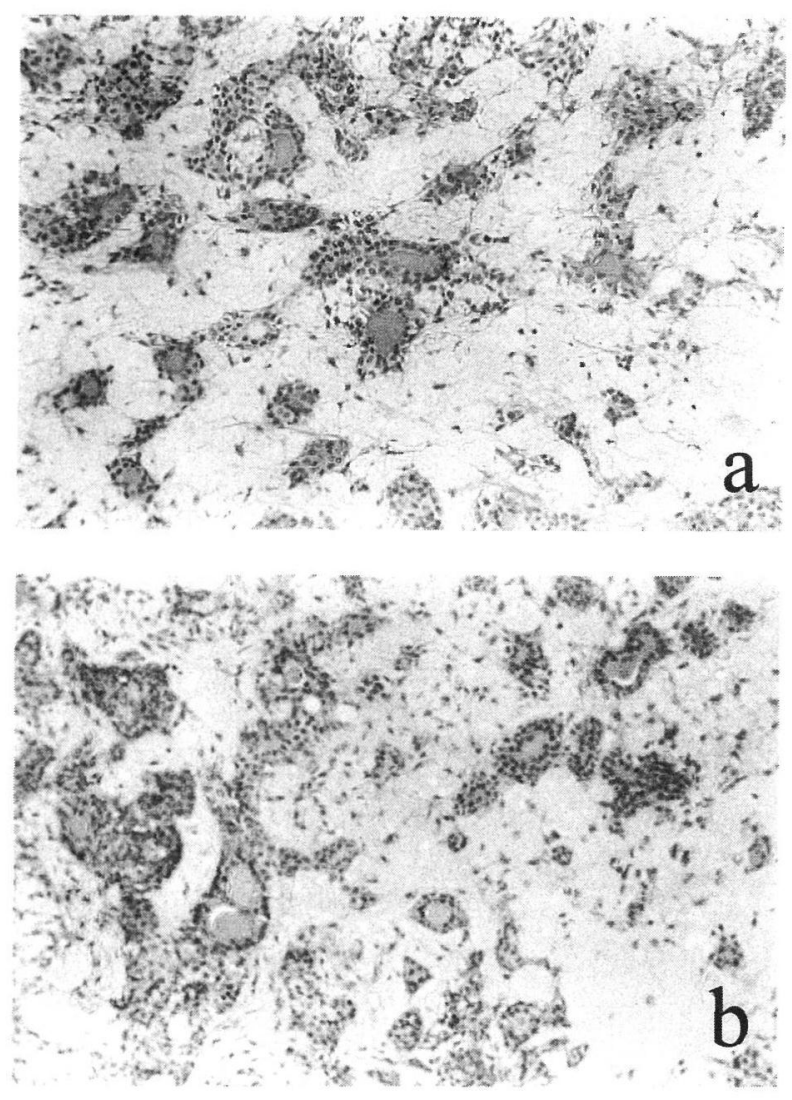

図 3 病理所見 $(\mathrm{HE}$ 染色, $\times 200)$

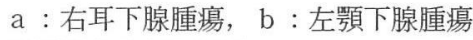
両腫瘍とも病理組織は多形腺腫であった。

耳下腺浅葉組織とともに腫瘍を顔面神経を末梢まで温存 しながら切除した，両腫瘍ともに癒着を認めず容易に摘 出できた。

病理所見：肉眼所見では, 右耳下腺腫瘍は被膜飞包ま れ, 割面は分葉状, 乳白色であり, 左顎下腺腫瘍もまた 被膜に包まれ割面は分葉状, 乳白色でめった。組織所見 では両腫瘍ともに, 二層性の細胞よりなる腺管構造を示 す上皮成分之，先の周困を取り卷く粘液質之紡錐形の細 胞がみられる間葉成分を認め, 病理組織診断では両者々 も多形腺腫であった。また，上皮成分と間葉成分の割合 は病理切片の部分によっては差があるが，特に右耳下腺 腫瘍と左顎下腺腫瘍に差はなかった，悪性変化を疑ら活 発な細胞分裂, 周囲組織への浸潤も認めなかった(図 3 ).

\section{考察}

多形腺腫は喠液腺腫瘍，特に耳下腺腫瘍では最も頻度
が高いものである。しかしながら，複数の大唾液腺に多 形腺腫を同時に有する症例はきわめて少ない，海外の報 告例では, Byrne ら ${ }^{1)} 167$ 例の耳下腺腫瘍中 3 例の両 側耳下腺腫瘍，Turnbull $5^{22}$ は大唾液腺腫瘍2072例中 27 例飞複数の唾液腺飞多形腺腫，そのらち 1 例のみに耳 下腺之顎下腺に多形腺腫を有したとの報告している。 た Sataloff ら ${ }^{3)}$ ，Becker ら ${ }^{4)}$ にるる両側深葉の耳下腺多 形腺腫症例の報告がある。淰かには Foote ら 5 ) が耳下腺 特よび同側顎下腺に多形腺腫を有した症例を報告してい る.

国内では安部ら 6 , 古川ら 7 の両側耳下腺多形腺腫症 例の 10 数例の報告の久である. 複数の大唾液腺に生じた 多形腺腫と乙ては，耳下腺と対側靧下腺江多形腺腫を有 した例は今まで報告がない。

成因に関する報告としては Nagler ら ${ }^{8)}$ は幼少時に放 射線照射の既往のある右耳下腺括よび右顎下腺の多形腺 腫の症例を, Takeichi 5 9) の広島の原爆被爆生存者に 和ける多形腺腫の発生率が非被爆者に和ける発生率と比 較して有意に多いという報告を引用し，放射線被曝が多 形腺腫を発生，多発させた可能性を述べている。乙かし ながら本症例では放射線被曝の既往はなかった。

また，良性であるにもかかわらず，多形腺腫の肺など 多藏器への転移が報告されている. Chen ${ }^{10)}$ や Freeman $ら^{11)}$, Shinohara $5^{12)}$ によると，多形腺腫の転移は高度 な細胞分裂像预よび浸潤増殖像を示寸が良性像を保つと 述べている. Wenig ら ${ }^{13)}$ はフローサイトメトリーを用 いて原発括よび転移腫場の DNA プロイディパターンを 調べ，両者とも diploid patternであり，組織像は両者 とも上皮成分之間葉成分持ち，上皮成分は紡錘形の筋 上皮型細胞に囲まれた腺管構造，間質成分は粘液質，軟 骨様のマトリックスと筋上皮型細胞よりなり，悪性所見 である異型，活発な細胞分裂像，周囲組織への浸潤，神 経怙よび血管への浸潤等はみられないと述べている。本 症例では両腫瘍ともに細胞分裂像や被膜の浸潤像はみら れず，顎下腺腫瘍から耳下腺への転移は考光にくい。 た不完全な手術症例や核出術を施行された多形腺腫症例 では被膜の損傷により細胞播種による再発も知られてい るが, 本症例では特に左顎下腺の手術歴はなかった.よっ て発生としては両者は個別に発生したと考光られる。

長期間を経た多形腺腫は悪性化することが知られてい るが，本症例は左顎下腺腫瘍については10年以上経って いるが，悪性の所見はみられなかった。 


$$
\text { まとめ }
$$

耳下腺と対側顎下腺に多形腺腫を同時に有したきわめ てまれな1例を経験した。

多形腺腫も多発することがあるので原発部位以外の喠 液腺も精査する必要がある.

な拈, 本論文の要旨は, 第73回日耳鼻京滋合同地方部会, 第 12回口腔・咽頭科学会にて発表した.

\section{参考文献}

1) Byrne MN and Spector JG : Parotid masses; evaluation, analysis, and current management. Laryngoscope 98 : $99 \sim 105,1988$.

2 ) Turnbull $\mathrm{AD}$ and Frazell EL : Multiple tumors of the major salivary glands. Am J Surg $118: 787 \sim 789,1969$.

3 ) Sataloff RT, Price DB and Roberts BR : Bilateral synchronous mixed tumors of the parotid glands. Arch Otolaryngol Head Neck Surg $113: 880 \sim 881,1987$.

4) Becker FF and Tabb HG : Bilateral benign mixed tumor of the deep lobe of the parotid gland. Arch Otolaryngol $94: 158 \sim 161,1971$.

5 ) Foote FW and Frazell EL : Tumor of the major salivary glands. Atlas of Tumor Pathology. section N, Fasc. II. Armed Forces Institute of Pathology, Washington, 1954.

6 ) 安部治彦, 井上都子 : 両側同組織型耳下腺腫瘍の遺后性に 関する一考察. 日耳鼻 $94: 325 \sim 332,1991$.

7 ) 古川勝朗, 白神か扣り, 中島智子, 他 : 両側性に発生した
耳下腺多形腺腫例. 耳鼻臨床 $88: 59 \sim 63,1995$.

8 ) Nagler RM and Laufer D : Synchronous pleomorphic adenomas of the major salivary glands; a case report. Oral Surg Oral Med Oral Patholoral Oral Radiol Endod 87 : 735 737, 1999.

9 ) Takeichi N, Hirose F, Yamamoto H, et al : Salivary gland tumors in atomic bomb survivors, Hiroshima, Japan ; II. pathologic study and supplementary epidemiologic observations. Cancer $52: 377 \sim 385,1983$.

10) Chen KT : Metastasizing pleomorphic adenoma of the salivary gland. Cancer $42:$ 2407 2411, 1978.

11) Freeman SB, Kennedy KS, Parker GS, et al : Metastasizing pleomorphic adenoma of the nasal septum. Arch Otolaryngol Head Neck Surg $116: 1331 \sim 1333,1990$.

12) Shinohara M, Ikebe $T$, Nakamura $S$, et al : Multiple pleomorphic adenomas arising in the parotid and submandibular lymph nodes. Br J Oral Maxillofac Surg 34 : 515 519, 1996.

13) Wenig BM, Hitchcock CL, Ellis GL, et al : Metastsizing mixed tumor of salivary glands; a clinicopathologic and flow cytometric analysis. Am J Surg Pathol $16: 845 \sim$ 858, 1992.

$$
\left.\begin{array}{l}
\text { 原稿受付 : 平成 } 12 \text { 年 } 9 \text { 月 } 13 \text { 日 } \\
\text { 原稿採択 : 平成 } 12 \text { 年 } 10 \text { 月 } 25 \text { 日 } \\
\text { 別刷請求先 : 瀧 正勝 } \\
\text { 干 } 523-0892 \text { 近江八幡市出町 } 395 \\
\text { 近江八幡市民病院耳鼻咽喉科 }
\end{array}\right)
$$

